ACTA UNIVERSITATIS WRATISLAVIENSIS No 3928

Slavica Wratislaviensia CLXXI • Wrocław 2020

DOI: $10.19195 / 0137-1150.171 .10$

Data przesłania artykułu: 6.10 .2018

Data akceptacji artykułu: 21.02.2019

\author{
DANUTA PYTEL-PANDEY
}

Uniwersytet Wrocławski, Polska

\title{
Problemy współczesnej komunikacji językowej. Kilka uwag o budowaniu relacji nadawca-odbiorca
}

Gdy słucham, co mówisz, słyszę, kim jesteś. Ralph W. Emerson

Codziennie wielokrotnie wchodzimy w kontakt językowy z różnymi rozmówcami. Często komunikacja przynosi nam satysfakcję i zadowolenie, bywa jednak też tak, że czujemy się zawiedzeni, a nasze oczekiwania związane z nią nie zostają spełnione. Co jest przyczyną tego, że kontakt językowy podjęty z interlokutorem przebiega inaczej, niż byśmy tego oczekiwali? Jak sprawić, by relacja pomiędzy rozmówcami była właściwa i przyczyniała się do sukcesu komunikacyjnego? W jaki sposób świadomie budować odpowiednią relację na linii nadawca-odbiorca i umiejętnie ją podtrzymywać aż do zakończenia aktu komunikacji i osiągnięcia zamierzonego celu? Próby udzielenia odpowiedzi na te pytania niezmiennie podejmują badacze reprezentujący wiele dziedzin nauki, ponieważ proces komunikacji jest zjawiskiem bardzo złożonym, wielopłaszczyznowym, zawierającym czynniki o charakterze psychicznym, społecznym, socjalnym, kulturowym, językowym czy światopoglądowym. Osiągnięty rezultat jest wypadkową wszystkich wymienionych parametrów. W związku ze zmianami obserwowanymi w sposobie życia i postrzegania rzeczywistości zachodzącymi we wszystkich społecznościach problem budowania relacji na linii nadawca-odbiorca dopóki istnieje homo loquens, prawdopodobnie się nie zdezaktualizuje. Dzieje się tak, gdyż: „człowiek podlega oddziaływaniu otaczającego go świata i sam na ten świat oddziałuje" 1 . Z tego powodu zagadnienie budowania relacji na linii nadawca-odbiorca zasługuje na to, aby stać się przedmiotem niniejszego opracowania.

${ }^{1}$ T. Tomaszewski, Wstęp do psychologii, Warszawa 1969, s. 142. 
Analiza oparta jest przede wszystkim na badaniach Friedemanna Schulza von Thuna, zawartych między innymi w książce Sztuka rozmawiania. Analiza zabu$r z e n^{2}$ i modelu komunikacji międzyosobowej, nazywanym także modelem poczwórnego ucha, tam zamieszczonej. Jest to pochodzące z początku lat osiemdziesiątych ubiegłego wieku psycholingwistyczne podejście do mechanizmu działania komunikacji międzyludzkiej, które zyskało uznanie w świecie nauki. Uważam, że ma ono duże znaczenie $w$ badaniach nad relacjami międzyludzkimi zachodzącymi podczas procesu komunikacji.

Proponowany przez Schulza von Thuna schemat zakłada, że wypowiedź składa się z czterech przenikających się wzajemnie płaszczyzn.

Model poczwórnego ucha można interpretować następująco:

ZAWARTOŚĆ RZECZOWA

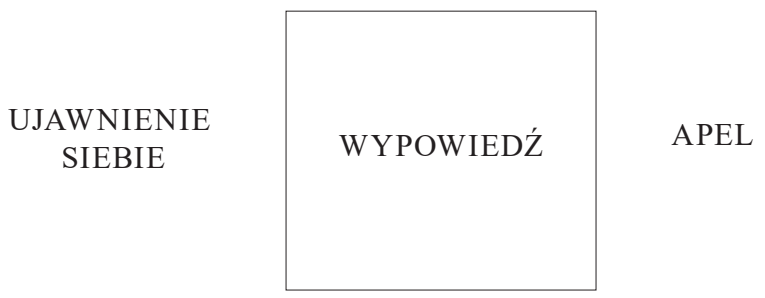

RELACJA WZAJEMNA ${ }^{3}$

\section{Zawartość rzeczowa}

Zawartość rzeczowa mówi, jak jasno i zrozumiale przekazywać swojemu rozmówcy informacje o aktualnym stanie rzeczy, takim jak dane, fakty, wydarzenia przeszłe, obecne lub przyszłe, o których chce poinformować nadawca, będące częścią jego przekazu ${ }^{4}$. Można powiedzieć, że nadawca ujawnia w niej swoją szeroko rozumianą kompetencję językową i komunikacyjną, którą Aleksy Awdiejew definiuje jako nabytą w danej społeczności „umiejętność produkcji i interpretacji wypowiedzi werbalnych i niewerbalnych, na podstawie odniesienia do wspólnie akceptowanych schematów wyobrażeniowych" ${ }^{\text {" }}$. Niedostateczna kompetencja językowa i/lub komunikacyjna powoduje, że przekaz staje się niejasny, mało zrozumiały albo nawet zupełnie niezrozumiały dla odbiorcy. Przykładem sytuacji,

${ }^{2}$ F. Schulz von Thun, Sztuka rozmawiania. Analiza zaburzeń (Miteinander reden 1. Störungen und Klärungen. Allgemeine Psychologie der Kommunikation, 1981), przeł. P. Włodyga, Kraków 2001 (w artykule cytowana tylko polska publikacja).

${ }^{3}$ Ibidem, s. 13. O znaczeniu modelu F. Schulza von Thuna zob. też L. Cirko, Akceptacja w komunikowaniu się. Między preskryptywizmem a permisywizmem, Wrocław 2009, s. 92-98.

${ }^{4}$ F. Schulz von Thun, Sztuka rozmawiania..., s. 12.

${ }^{5}$ A. Awdiejew, Świadomość i nieświadomość w komunikacji, [w:] Świadomość językowa w komunikowaniu, red. M. Steciąg, M. Bugajski, Zielona Góra 2012, s. 46. 
w której zawartość rzeczowa wypowiedzi może być źle zrozumiana przez odbiorcę, jest użycie przez nadawcę ukrytych aktów mowy, języka nieznanego albo słabo znanego odbiorcy, posługiwanie się żargonem, językiem fachowym w kontaktach z przedstawicielami innej grupy zawodowej itp.

Przykładowe sytuacje obrazują niewłaściwe zinterpretowanie przez odbiorcę zawartości rzeczowej wypowiedzi:

- ukryty akt mowy:

Nadawca — osoba podróżująca pociągiem w przedziale, w którym jest otwarte okno i z tego powodu powstaje przeciąg, wypowiada następujące zdanie: Przeciagi sa szkodliwe dla zdrowia.

Odbiorca/odbiorcy — współpasażerowie, nie reagują na usłyszaną wypowiedź albo tylko przytakują, mówiąc na przykład: Tak, to prawda.

Nadawca chciał jednak przez ukryty akt mowy poprosić o zamknięcie okna, wypowiedź jego została zatem niepoprawnie odczytana — zawartość rzeczowa wypowiedzi była niewłaściwie odebrana przez adresata/adresatów i cel komunikacyjny (apel według schematu Schulza von Thuna), którym była pośrednio wyrażona prośba o zamknięcie okna, w konsekwencji nie zostanie zrealizowany.

- niedostateczna kompetencja komunikacyjna:

a) spowodowana nieznajomością/niezbyt dobrą znajomością języka, którym posługuje się nadawca:

Nadawca - na przykład turysta niemieckojęzyczny, nieznający miasta, wypowiada następujące pytanie/prośbę o wskazanie drogi do dworca: Könnten Sie mir, bitte, den Weg zum Bahnhof zeigen?

Odbiorca - Polak nieznający języka niemieckiego. Zawartość rzeczowa w pytaniu skierowanym do odbiorcy niewładającego językiem nadawcy nie będzie mogła być właściwie odczytana (zrozumienie dodatkowo utrudni brak internacjonalizmów w wypowiedzi). Cel komunikacyjny nadawcy nie zostanie osiągnięty.

b) będąca skutkiem nieznajomości, języka fachowego czy żargonu, na przykład studenckiego. Zawartość rzeczowa wypowiedzi: Przestań bleblać, zgarniaj siano $i$ wbijaj na bibkę ${ }^{6}$, nie będzie prawdopodobnie zrozumiała dla kogoś, kto nie jest studentem.

\section{Ujawnienie siebie}

Ujawnianie siebie - kiedy ktoś coś mówi od siebie, odsłania/prezentuje także część siebie ${ }^{7}$ Każda wypowiedź jest bowiem małą próbką naszego charakteru, kultury osobistej, wykształcenia. Komunikujemy świadomie lub nieświadomie, przekazując odbiorcy wiedzę na temat naszej osoby — stanu emocjonalnego, motywów działania, światopoglądu, wyznawanych wartości itp. Informacje te

${ }^{6}$ T. Repeta, Zgarniaj siano i wbijaj na bibkę, czyli meandry gwary studenckiej, http://wiadomosci.gazeta.pl/wiadomosci/1,156046,17751781,Zgarniaj_siano_i_wbijaj_na_bibke_czyli_meandry_gwary.html [dostęp: 1.09.2018].

${ }^{7}$ F. Schulz von Thun, Sztuka rozmawiania..., s. 12. 
zawarte są w sposobie komunikacji - budowie i długości wypowiedzi, zasobie używanego słownictwa, łatwości bądź trudności odbioru przekazu nadawcy i właściwego reagowania na niego. Trzeba pamiętać też o niejęzykowych elementach komunikacji, do których należą: gestykulacja, wyraz mimiczny twarzy, dotyk i kontakt fizyczny, wygląd fizyczny, dźwięki paralingwistyczne, spojrzenia i wymiana spojrzeń, dystans fizyczny między rozmówcami, pozycja ciała w trakcie rozmowy oraz organizacja środowiska ${ }^{8}$. Wypracowany przez Alberta Mehrabiana podział procentowy składników komunikacji międzyludzkiej zakłada, że tylko niecałe 7\% informacji przekazywanych jest werbalnie, $38 \%$ to sposób mówienia, na przykład intonacja, tempo, barwa głosu. Pozostałe 55\% informacji przekazywanych jest ,językiem ciała" - niewerbalnie ${ }^{9}$. Nie na darmo mądrość ludowa głosi: „Jak cię widzą, tak cię piszą”. Mimo że reguła 7-38-55 jest krytykowana, jeśli chodzi o jej rozkład procentowy (przez innych badaczy podawane są różne wartości procentowe ${ }^{10}$ ) — nie można nie doceniać ogromnego znaczenia pozawerbalnych komponentów komunikacji ${ }^{11}$. W czasie wypowiedzi nadawca odsłania zatem siłę/słabość swojego charakteru, stan psychiki i stopień zaangażowania w osiągnięcie wytyczonego przez siebie celu komunikacji na trzech płaszczyznach:

- słowa,

- sposobu wyartykułowania go,

- mowy ciała.

\section{Relacja wzajemna}

Relacja wzajemna pokazuje, jak nawiązujemy kontakt z rozmówcą. W tym, jak się do niego zwracamy, wyrażamy to, co o nim myślimy, a nasza postawa wobec niego powoduje, że czuje się on w naszej obecności akceptowany i w pełni wartościowy lub wręcz przeciwnie - odrzucony, lekceważony i traktowany niepoważnie. Odbiorca interpretuje więc, co przekaz mówi o relacji nadawcy do jego osoby. Podejmując albo rezygnując $\mathrm{z}$ reakcji na słowa nadawcy, słuchający daje wyraz temu, czy akceptuje stosunek rozmówcy do swojej osoby. Reakcja pozytywna oznacza akceptację postawy współrozmówcy. Reakcja negatywna lub brak jakiejkolwiek reakcji, ignorowanie osoby mówiącego, to wyraz nieakceptowania

${ }^{8}$ Z. Nęcki, Komunikowanie niewerbalne, [w:] idem, Komunikacja międzyludzka, Kraków 1996, s. 212-213. O znaczeniu komunikacji niewerbalnej zob. też J. Kasprzyk, Z. Lizak, Komunikacja, czyli sztuka porozumiewania się, Warszawa 2007, s. 9-11.

9 A. Mehrabian, https://pl.wikipedia.org/wiki/Albert_Mehrabian [dostęp: 28.08.2018].

${ }^{10}$ Justyna Kasprzyk i Zygmunt Lizak podają inne wartości: „słowa w rozmowach bezpośrednich to mniej niż $35 \%$ informacji, a ponad $65 \%$ informacji ludzie przekazują pozawerbalnie, $w$ tym mową ciała" - eidem, Komunikacja..., s. 9.

11 Potwierdza to Ida Kucz: „W latach 60. i 70. ub. wieku przeprowadzono badania nad rolą składnika werbalnego i niewerbalnego w interpretacji ogólnego znaczenia przekazu, które doprowadziły do stwierdzenia, iż składnik niewerbalny ma tu znacznie większy udział" — eadem, Psychologia języka i komunikacji, Warszawa 2005, s. 225. 
nadawcy i/lub jego postawy wobec rozmówcy. Rodzaj relacji między rozmówcami determinowany jest przez wiek, płeć, rodzaj wzajemnych powiązań i zależności. Układ symetryczny — rozmówcy mają ten sam status, pozycję społeczną: układ mąż-żona, siostra-brat, koledzy w pracy na równorzędnych stanowiskach, przyjaciele. Układ niesymetryczny - komunikujący się mają różne pozycje: układ podwładny-przełożony, nauczyciel-uczeń, rodzice-dzieci. Na sposób komunikacji i objawianie wzajemnych relacji ma wpływ też miejsce komunikacji oraz obecność świadków.

\section{Apel}

Apel jest potwierdzeniem tego, że gdy ktoś coś mówi, to robi to w jakimś konkretnym celu ${ }^{12}$, nie rzuca przysłowiowych słów na wiatr. Chce coś osiągnąć, wywrzeć jakiś wpływ, ma jakąś intencję komunikacyjną. Apel zawiera zatem informacje o efekcie komunikacji jakiego spodziewa się nadawca, jego potrzebach i oczekiwaniach, o skutku, jakiego pragnie nadawca ${ }^{13}$. Informacje te mogą zostać wyartykułowane, sygnalizowane wprost albo być ukryte w pośrednich aktach mowy. Niejawne wyrażenie intencji komunikacyjnej nadawcy może być spowodowane różnymi przyczynami ${ }^{14}$.

Schulz von Thun podaje następujący przykład różnej interpretacji tej samej wypowiedzi: TU JEST COŚ ZIELONEGO zgodnie z modelem poczwórnego ucha:

Wypowiedź męża:

Zawartość rzeczowa - Tu jest coś zielonego.

Ujawnienie siebie - Nie wiem, co to jest.

Wzajemna relacja - Ty to będziesz wiedzieć.

Apel - Powiedz mi, co to jest.

Interpretacja usłyszanej wypowiedzi przez żonę podana przez Schulza von Thuna:

Zawartość rzeczowa - Tu jest coś zielonego.

Ujawnienie siebie — To mi nie smakuje.

Wzajemna relacja — Jesteś kiepska gospodynia.

Apel - Następnym razem usuń to zielone! ${ }^{15}$

12 F. Schulz von Thun, Sztuka rozmawiania..., s. 12.

${ }^{13}$ Chciałabym tu przytoczyć uwagę Mariana Bugajskiego, który pisze, że: „Nie należy mylić skutków komunikowania z jego skutecznością. Skutek bowiem — to po prostu następstwo jakiegoś działania, jego wynik (rezultat). Każde działanie może być skuteczne bądź nie. Skuteczne jest wtedy, gdy przynosi efekty zgodne z przyjętymi założeniami, nieskuteczne wtedy, gdy nie osiągamy oczekiwanych rezultatów. Gdy mówimy o skuteczności komunikowania, zakładamy więc świadome działanie nadawcy, którego zamierzeniem jest określony wpływ na odbiorcę komunikatu" — idem, Język w komunikowaniu, Warszawa 2006, s. 440.

14 Zob. F. Schulz von Thun, Sztuka rozmawiania..., s. 12. Na temat powodów ukrywania intencji komunikacyjnej nadawcy zob. D. Pytel-Pandey, Dyrektywne akty mowy realizowane jako akty pośrednie, „Slavica Wratislaviensia” 156, 2012, s. 150-158.

15 F. Schulz von Thun, Sztuka rozmawiania..., s. 63. 
Podana przez autora Sztuki rozmawiania interpretacja tej wypowiedzi nie jest jedyną możliwą, może być ich wiele. Są one uzależnione od stanu emocjonalnego i wzajemnego nastawienia do siebie rozmówców. Przyjazne nastawienie do rozmówcy pociąga za sobą życzliwy odbiór jego słów, nawet jeżeli treść wypowiedzi nie jest wygodna dla odbiorcy. Jeden z możliwych odbiorów treści wypowiedzi: TU JEST COŚ ZIELONEGO mógłby być następujący:

Zawartość rzeczowa - Tu jest coś zielonego.

Ujawnienie siebie - Nie lubię zielonego w zupie.

Wzajemna relacja - Jako dobra żona powinnaś na przyszłość lepiej poznać moje upodobania kulinarne.

Apel - Proszę cię, następnym razem nie dodawaj zielonego do zupy!

Nietrudno zauważyć, że wszystkie wymienione płaszczyzny przenikają się wzajemnie i są od siebie uzależnione, nie ma możliwości stworzenia wypowiedzi którejś z nich pozbawionej. W modelu Schulza von Thuna zawartość rzeczowa i apel bliższe są sferze treści, a ujawnianie siebie i relacja wzajemna odnoszą się bardziej do sfery emocjonalnej interlokutorów.

Jak wcześniej napisałam, każda z części składowych kwadratu komunikacyjnego niesie z sobą wycinek informacji na temat osoby nadawcy. Dzieje się to zgodnie zgodnie z pięcioma aksjomatami psychologa i lingwisty Paula Watzlawicka zawartymi w pracy Menschliche Kommunikation ${ }^{16}$, na których opiera się model poczwórnego ucha Schulza von Thuna. Brzmią one następująco:

- Aksjomat 1: NIE MOŻNA NIE KOMUNIKOWAĆ,

- Aksjomat 2: KAŻDA KOMUNIKACJA MA ASPEKT ZAWARTOŚCI I RELACJI

- Aksjomat 3: NATURA RELACJI JEST UWARUNKOWANA UPORZĄDKOWANIEM SEKWENCJI ZDARZEŃ KOMUNIKACYJNYCH MIĘDZY KOMUNIKUJĄCYMI SIĘ,

- Aksjomat 4: LUDZIE KOMUNIKUJĄ SIĘ ZARÓWNO CYFROWO, JAK I ANALOGOWO,

- Aksjomat 5: KOMUNIKACJA JEST SYMETRYCZNA LUB KOMPLEMENTARNA ${ }^{17}$.

W budowaniu relacji nadawca-odbiorca ważne są wszystkie, ale w szczególności pierwszy jako podstawowe założenie wszelkich ludzkich zachowań werbalnych i niewerbalnych.

Skoro człowiek nie może nie komunikować, a każde nasze zachowanie werbalne i niewerbalne jest przekazem jakiejś informacji, to budowanie i podtrzymywanie właściwego kontaktu na linii nadawca-odbiorca (używam sformułowania

${ }^{16}$ P. Watzlawick, J. H. Beaven, D. D. Jackson, Menschliche Kommunikation, Bern-Stuttgart-Wien 1969.

${ }^{17}$ P. Watzlawick, https://www.paulwatzlawick.de/axiome.html [dostęp: 10.09.2018]. Zob. też W. Laskowski, Aksjomaty teorii komunikacji, https://pl.scribd.com/presentation/208698313/AKSJOMATY-TEORII-KOMUNIKACJI [dostęp: 25.04.2018]. 
„właściwy kontakt”, bo zamiarem interlokutorów może być wytworzenie relacji zarówno pozytywnych, jak i negatywnych) zachodzi podczas całego kontaktu z współrozmówcą. Następuje on za pośrednictwem trzech kanałów komunikacyjnych: wzrokowego, czuciowego i słuchowego ${ }^{18}$.

Przy uwzględnieniu parametrów werbalnych i niewerbalnych oraz ich rozłożenia ilościowego $\mathrm{w}$ akcie komunikacji można powiedzieć, że z pozycji mówiącego budowanie relacji na linii nadawca-odbiorca w interakcjach face-to-face $\boldsymbol{e}^{19}$ powstaje według następującego schematu:

PRZEDE WSZYSTKIM:

O B S E R W U J Ę / W I D Z E

NASTĘPNIE:

CZUJĘ / O C ENIAM / P O D E JMU JE DECYZJE O TREŚCI KOM U N I KAT U

POTEM:

WYRA ŻA S S OWAMI

NA KOŃCU:

\section{OCZEKUJĘ SPODZIEWANEJ REAKCJI ROZMÓWCY}

Skoro nasze zachowanie jest ciągłym komunikowaniem, to musimy się go w jakiś sposób nauczyć, wiedzieć, co należy uczynić w danej sytuacji, aby osiągnąć zamierzony cel. Następuje to w procesie socjalizacji, przyswajania norm społeczno-kulturowych. Jak pisze Stanisław Grabias: „w każdej sytuacji społecznej wyodrębniają się wzory zachowań regulujące porządek interakcji: przywilej jej rozpoczęcia i zakończenia, tempo, rodzaj obranego kodu, bardziej utarty lub bardziej zindywidualizowany tok jej przebiegu" ${ }^{20}$. Pożądaną relację nadawca-odbiorca warunkuje znajomość tych norm i odpowiednie dopasowanie ich do konkretnego rozmówcy, do roli, jaką w danym momencie pełni. Role te mogą mieć charakter stały lub przejściowy.

${ }^{18}$ Zob. M. Kaczmaryk, Ogólne zasady komunikacji nadawca-odbiorca, www.witrynawiejska.org.pl [dostęp: 7.04.2018].

19 Zob. E. Goffman, Czlowiek w teatrze życia codziennego (The Presentation of Self in Everyday Life, 1959), przeł. H. Datner-Śpiewak, P. Śpiewak, Warszawa 2008, s. 45: „Interakcję face-to-face można dla celów prowadzonych tu analiz w przybliżeniu zdefiniować jako wzajemny wpływ na postępowanie jednostek znajdujących się w bezpośredniej fizycznej bliskości. Poszczególne interakcje można określić jako wszelkie działania występujące przy jakiejś jednej okazji, kiedy współobecność danego zespołu jednostek jest nieprzerwana. W tym wypadku słowo »interakcja« można zastąpić słowem »spotkanie« (encounter). »Występ« (performance) można zdefiniować jako wszelką działalność danego uczestnika interakcji w danej sytuacji służącą wpływaniu w jakiś sposób na któregoś z innych jej uczestników".

${ }^{20}$ S. Grabias, Język w zachowaniach społecznych, Lublin 1997, s. 253. 
Na budowanie i rodzaj relacji między rozmówcami będą miały wpływ także:

1. stopień sformalizowania kontaktu: służbowe/oficjalne, prywatne/nieoficjalne, intymne;

2. miejsce kontaktu: formalne - na gruncie służbowym, urzędowym; nieformalne - na gruncie prywatnym;

3. obecność osób trzecich: w obecności świadków lub bez;

4. chęć rozmówców do zaistnienia wzajemnego kontaktu: chciane/pożądane, niechciane/niepożądane, obojętne. Czynnik ten jest ściśle związany z emocjonalnością interlokutorów;

5. częstotliwość kontaktów: jednorazowe (na przykład obcy na ulicy); sporadyczne z obcymi, sporadyczne ze znajomymi lub spokrewnionymi; częste z obcymi znajomymi (na przykład sąsiedzi); częste z zaprzyjaźnionymi, spokrewnionymi; stałe (codzienne lub niemal codzienne) z bliskimi sobie ludźmi, rodziną;

6. oczekiwana korzyść - im większa jest oczekiwana korzyść z osiągnięcia celu wypowiedzi, tym większa zdolność/gotowość rozmówców do ustępstw na rzecz rozmówcy i odwrotnie - im mniejsza korzyść, tym chęć ustępstw mniejsza;

7. atrakcyjność rozmówców - zarówno fizyczna, jak i intelektualna, a także każda inna według subiektywnej oceny rozmówców. Atrakcyjność może mieć ścisły związek z potencjalnie możliwymi korzyściami płynącymi z wzajemnego kontaktu;

8. kompetencje komunikacyjne rozmówców lub ich brak.

Brak kompetencji komunikacyjnej na niezbędnym poziomie prowadzi do nieporozumień między interlokutorami, ale mogą one powstawać także z innych przyczyn, na przykład zdrowotnych. Do najważniejszych zakłóceń językowych utrudniających właściwą relację nadawca-odbiorca, powodujących u rozmówców zniecierpliwienie i niechęć do dalszej komunikacji, zwłaszcza jeśli obserwuje się ich nagromadzenie, za Zbigniewem Nęckim zaliczę:

— zająknienia;

— powtórzenia — słowa lub kilku słów, powtórki automatyczne;

— ominięcia - opuszczanie części wyrazu;

— akty paralingwistyczne - serie dźwięków, które nie tworzą słów ani ich gramatycznych części: eeee..., hmmm...;

- pomyłki językowe;

— słowa i frazy, które nie zawierają znaczenia, lecz przygotowują do wypowiedzenia właściwego zdania: wiesz ..., kur**, to znaczy..., tego ... oraz inne ${ }^{21}$.

${ }^{21}$ Zob. Z. Nęcki, Komunikacja międzyludzka..., s. 209. Nęcki dodaje jeszcze inne zakłócenia: „-zdania niezakończone — zdania, które są przerwane, a mówca kontynuuje wypowiedź, nie kończąc zdania przerwanego;

- fraza poprawiona - osoba mówiąca przerywa wypowiadaną frazę, wprowadza poprawkę treściową lub gramatyczną i kontynuuje wypowiedź tematycznie nawiązującą do fazy przerwanej;

— fraza powtórnie rozpoczynana — przerwanie frazy już rozpoczętej i rozpoczęcie od nowa, bez wprowadzenia jakichkolwiek poprawek; 
W budowaniu relacji nadawca-odbiorca należy wreszcie pamiętać o tak zwanym pierwszym wrażeniu, które zwykle rzutuje na przyszłe relacje. Podczas tego kontaktu doświadczamy bodźców powodujących powstanie wrażenia, którego nie da się powtórzyć w przyszłości. Pierwszych kilkanaście sekund i słów będzie miało wpływ na dalsze kontakty z odbiorcą. Złe początkowe wrażenie trudno jest naprawić przy następnych spotkaniach ${ }^{22}$.

\section{Podsumowanie}

Znajomość zasady poczwórnego ucha wypracowanej przez Friedemanna Schulza von Thuna, opartej na aksjomatach Paula Watzlawicka, oraz innych przedstawionych w tej analizie uwarunkowań mających bezpośredni wpływ na rodzaj i jakość relacji na linii nadawca-odbiorca ma duże znaczenie dla komunikacji międzyludzkiej. Zdobycie wiedzy na ich temat pomoże zbudować trwałą relację między rozmówcami zgodnie z myślą Ralpha W. Emersona: „Gdy słucham, co mówisz, słyszę, kim jesteś”. Może się ona także okazać pomocna w przełamywaniu barier uniemożliwiających prowadzenie satysfakcjonującego kontaktu językowego, co jest bardzo ważne dla każdego człowieka, a w szczególności filologa.

\section{Bibliografia}

Awdiejew A., Świadomość i nieświadomość w komunikacji, [w:] Świadomość językowa w komunikowaniu, red. M. Steciąg, M. Bugajski, Zielona Góra 2012.

Bugajski M., Język w komunikowaniu, Warszawa 2006.

Cirko L., Akceptacja w komunikowaniu się. Między preskryptywizmem a permisywizmem, Wrocław 2009.

Grabias S., Język w zachowaniach społecznych, Lublin 1997.

Goffman E., Czlowiek w teatrze życia codziennego (The Presentation of Self in Everyday Life, 1959), przeł. H. Datner-Śpiewak, P. Śpiewak, Warszawa 2008.

Kasprzyk J., Lizak Z., Komunikacja, czyli sztuka porozumiewania się, Warszawa 2007.

Kucz I., Psychologia języka i komunikacji, Warszawa 2005.

Nęcki Z., Komunikacja międzyludzka, Kraków 1996.

Pytel-Pandey D., Dyrektywne akty mowy realizowane jako akty pośrednie, „Slavica Wratislaviensia” $156,2012$.

Schulz von Thun F., Sztuka rozmawiania. Analiza zaburzeń (Miteinander reden 1. Störungen und Klärungen. Allgemeine Psychologie der Kommunikation, 1981), przeł. P. Włodyga, Kraków 2001.

Tomaszewski T., Wstęp do psychologii, Warszawa 1969.

Watzlawick P., Beavin J. H., Jackson D. D., Menschliche Kommunikation, Bern-Stuttgart-Wien 1969.

— inne zakłócenia i pomyłki językowe, takie jak dłuższe przerwy w emisji dźwięku, fizjologiczne załamanie głosu" - ibidem, s. 210.

22 Zob. M. Kaczmaryk, Ogólne zasady komunikacji... 


\section{Źródła internetowe}

Kaczmaryk M., Ogólne zasady komunikacji nadawca-odbiorca, http://witrynawiejska.org.p1/strona-glowna/poradniki/item/29716-ogolne-zasady-komunikacji-nadawca-odbiorca [dostęp: 28.04.2018].

Laskowski W., Aksjomaty teorii komunikacji, https://pl.scribd.com/presentation/208698313/AKSJOMATY-TEORII-KOMUNIKACJI [dostęp: 25.04.2018].

Mehrabian A., https://pl.wikipedia.org/wiki/Albert_Mehrabian [dostęp: 28.08.2018].

Repeta T., Zgarniaj siano $i$ wbijaj na bibke, czyli meandry gwary studenckiej, http://wiadomosci. gazeta.pl/wiadomosci/1,156046,17751781,Zgarniaj_siano_i_wbijaj_na_bibke_czyli_meandry gwary.html [dostęp: 1.09.2018].

Watzlawick P., https://www.paulwatzlawick.de/axiome.html [dostęp: 10.09.2018].

\section{Problems of contemporary language communication. Some comments on building the sender-recipient relationship}

\section{Summary}

This article discusses the problems of modern language communication associated with setting up contacts between the listener and the speaker. The author analyzes the communicative model of four ears, which was proposed by the German psychologist Friedemann Schultz von Thun for the interpretation of speech messages, and Paul Watzlawick's five axioms of communication. The paper presents their influence on building relationships between interlocutors during a language contact.

Keywords: linguistic communication, speaker, listener

\section{Проблемы современной языковой коммуникации. Несколько комментариев к проблеме построения контакта между говорящим и слушающим}

\section{Резюме}

В настоящей статье рассматриваются проблемы современной языковой коммуникации, связанные с построением контактов между слушающим и говорящим. Автор анализирует коммуникативную модель „четырёх ушей”, которую предложил немецкий психолог Фридеманн Шульц фон Тун для интерпретации речевых сообщений, и аксиомы человеческой коммуникации Пола Вацлавика. В работе представлено их влияние на построение отношений между собеседниками во время языкового контакта.

Ключевые слова: языковая коммуникация, говорящий, слушающий 